\title{
Responses of Withania frutescens (L.) Pauquy (Solanaceae) Growing in the Mediterranean Area to Changes in the Environmental Conditions: An Approach of Adaptation
}

\section{OPEN ACCESS}

Edited by:

Ramona Marasco,

King Abdullah University of Science and Technology, Saudi Arabia

Reviewed by:

Marek Zivcak,

Slovak University of Agriculture,

Slovakia

Carmelo Maria Musarella, Mediterranea University of Reggio

Calabria, Italy

${ }^{*}$ Correspondence:

Abdelfattah El Moussaoui abdelfattah.elmoussaoui@

usmba.ac.ma

Mohammed Bourhia

bourhiamohammed@gmail.com

Ahmad Mohammad Salamatullah

asalamh@ksu.edu.sa

Specialty section:

This article was submitted to Ecophysiology,

a section of the journal

Frontiers in Ecology and Evolution

Received: 09 February 2021 Accepted: 25 June 2021

Published: 04 August 2021

Citation:

Moussaoui AE, Bourhia M, Jawhari FZ, Khalis H, Chedadi $M$, Agour A, Salamatullah AM, Alzahrani A, Alyahya HK, Alotaibi A,

Bousta D and Bari A (2021) Responses of Withania frutescens (L.)

Pauquy (Solanaceae) Growing in the Mediterranean Area to Changes in the Environmental Conditions: An

Approach of Adaptation.

Front. Ecol. Evol. 9:666005.

doi: 10.3389/fevo.2021.666005

\begin{abstract}
Abdelfattah El Moussaoui ${ }^{*}$, Mohammed Bourhia2*, Fatima Zahra Jawhari', Hind Khalis ${ }^{3}$, Mohamed Chedadi ${ }^{1}$, Abdelkrim Agour ${ }^{4}$, Ahmad Mohammad Salamatullah ${ }^{5 *}$, Abdulhakeem Alzahrani ${ }^{5}$, Heba Khalil Alyahya ${ }^{5}$, Asdaf Alotaibi ${ }^{5}$, Dalila Bousta ${ }^{1}$ and Amina Bari ${ }^{1}$

'Laboratory of Biotechnology, Environment, Agrifood, and Health, Faculty of Sciences, University Sidi Mohammed Ben Abdellah, Fez, Morocco, ${ }^{2}$ Laboratory of Chemistry-Biochemistry, Environment, Nutrition, and Health, Faculty of Medicine and Pharmacy, University Hassan II, Casablanca, Morocco, ${ }^{3}$ Laboratory of Geoscience, Environment and Associated Resources, Faculty of Sciences, University Sidi Mohammed Ben Abdellah, Fez, Morocco, ${ }^{4}$ Laboratory of Natural Substances, Pharmacology, Environment, Modeling, Health and Quality of Life, Faculty of Sciences, University Sidi Mohammed Ben Abdellah, Fez, Morocco, ${ }^{5}$ Department of Food Science and Nutrition, College of Food and Agricultural Sciences, King Saud University, Riyadh, Saudi Arabia
\end{abstract}

Background: Flora growth is always influenced by the environmental conditions that surround the plant.

The Objective of the Study: The present research work was undertaken to study the response of Withania frutescens (L.) Pauquy to changes in the environmental conditions by investigating topographical, climatological, morphological, histological, and phytochemical aspects influencing the plant's growth.

Materials and Methods: The topography of the study area was described using the Digital Terrain Model (DTM). The bioclimatic study was carried out using a climatological database (TerraClimate) used for an old period 1960-1970 (OP) and a new period 2000-2019 (NP). The histological study on stems, leaves, and roots was investigated according to protocols as described in the present study. The phytochemical analysis was assessed using a gas chromatograph coupled to a mass spectrophotometer after silylation.

Results: The topographical study showed that the selected stations varied in terms of topographical characteristics. The average annual precipitation recorded for the study area was $624 \mathrm{~mm} /$ year, and the thermal amplitude was around $34.64^{\circ} \mathrm{C}$. The morphometrical study revealed that the plant had changes in length and width from one zone to another. The histometrical study of organs showed changes in tissue structure over time and location. The phytochemical content in the studied plants was also found to vary over time and location.

Conclusion: Based on the obtained results, we could confirm that $W$. frutescens has developed alternate strategies to mitigate increasingly harsh environmental conditions.

Keywords: ecology, Withania frutescens, histology, morphometrics, phytochemical content 


\section{INTRODUCTION}

The drought in the north of Africa is the most severe to strike the region in the last decades, with serious impacts on agriculture and general economic activities for the countries concerned (Bourhia et al., 2020). The drought has profoundly disturbed the vegetation cover, inducing significant water stress and adaptation phenomena in plants, and impacts the ecological balance by which toxic plants have invaded the target area (Quezel, 1999; Di Ferdinando et al., 2014).

The Mediterranean ecosystem is considered one of the largest areas that has been affected by global climate change (Benabadji and Bouazza, 2000). It is thus fitting that serious changes have occurred in biodiversity including soil and vegetation cover degradation (Stambouli-Meziane and Bouazza, 2013).

Plants have been exposed to multiple interactive abiotic stressors such as extreme temperature, drought, and water stress. These stressors could be a result of global climate change. Consequently, extreme weather events have lead to aridity and vegetation cover degradation (Diffenbaugh et al., 2005; Christensen et al., 2007; Valladares et al., 2008). Harsh ecological conditions can present a complex challenge for plant development (Wollenweber et al., 2005; Valladares et al., 2008). Plants are substantially affected by the surrounding environment. When they undergo changed climatic conditions, plants develop adaptation strategies. Often, the modification of optimal conditions induces a series of changes affecting morphology, metabolism, growth, nutrition, and anatomy leading to plant stress (Chelli-Chaabouni, 2014).

The natural adaptation system can be defined as one of the biological characteristics that allow a species to survive and thrive in a given environment (Atkins and Travis, 2010). Adaptation should not be confused with accommodation. In the first case, the adaptive character is inscribed in the genome of the plant and all the descendants will present the same characteristics insofar as the sexual reproduction allows it. In the second case, it is the natural ability of plants to survive under environmental conditions that can be far from their ecological optimum. The constraints to adaptation are of three kinds: climatic constraints (water, wind, etc.), edaphic constraints (salty soils, mobile soils, etc.), biotic constraints (competition, association, etc.) (Malhi et al., 2014).

This work aimed to study the response of Withania frutescens (L.) Pauquy to change in the environmental conditions by investigating topographical, climatological, morphological, histological, and phytochemical factors that influence the plant's growth.

\section{MATERIALS AND METHODS}

\section{Description of Study Areas}

The study area was located at the East South East (ESE) of Fez City, Morocco (Figure 1A). It is characterized by the presence of cultivated and wild plant species. The average distance between the four selected stations is $5,000 \mathrm{~m}$. Coordinates, altitude, and exposure of each station are reported in Table 1.
TABLE 1 | Coordinates, altitudes, and exposures of selected study areas.

\begin{tabular}{lccc}
\hline Stations & Coordinates & Altitudes & Exposures \\
\hline A1 & $34^{\circ} 01^{\prime} 43^{\prime \prime} \mathrm{N} ; 4^{\circ} 48^{\prime} 46^{\prime \prime} \mathrm{W}$ & $271 \mathrm{~m}$ a.s.l. & $\mathrm{SW}$ \\
A2 & $34^{\circ} 00^{\prime} 44^{\prime \prime} \mathrm{N} ; 4^{\circ} 45^{\prime} 09^{\prime \prime} \mathrm{W}$ & $542 \mathrm{~m}$ a.s.l. & $\mathrm{S}$ \\
A3 & $33^{\circ} 59^{\prime} 57^{\prime \prime} \mathrm{N} ; 4^{\circ} 45^{\prime} 13^{\prime \prime} \mathrm{W}$ & $439 \mathrm{~m}$ a.s.l. & $\mathrm{S}$ \\
A4 & $33^{\circ} 59^{\prime} 39^{\prime \prime} \mathrm{N} ; 4^{\circ} 47^{\prime} 13^{\prime \prime} \mathrm{W}$ & $296 \mathrm{~m}$ a.s.l. & $\mathrm{SW}$ \\
\hline
\end{tabular}

SW, Southwest; S, South; W, West; N, North; m.a.s.I, Meters above sea level.

The study area extended over a perimeter of plateaus with little unevenness and relatively low heights that can be easily investigated. The topography of the study area was described by the Digital Terrain Model (DTM) (Figure 1B), which was generated based on the DTM of Northern Morocco and ASTER Global Digital Elevation Model. The DTM results revealed that the topography is a little accentuated and hilly due to the lithological nature of the region. The DTM demonstrated that the average elevation from the river bottoms to the surrounding hills ranged from 270 to $540 \mathrm{~m}$ a.s.l (Figure 1B). The slope map of the basin derived from the DTM revealed that the majority of the basin has gentle slopes, which vary between $6^{\circ}$ and $15^{\circ}$ (Figure 2A). The steepest slopes were mostly located in the temporal river system in the study area and were only detected in the peripheral areas with hydraulic networks.

\section{Pedological Analysis of the Natural Environment of $W$. frutescens}

Color identification was performed using the Munsell code (Ndiaye et al., 2012). pH was measured using a $\mathrm{pH}$ meter. The total soil limestone content and conductivity was measured to determine the soil organic matter as described in the earlier data (Diallo et al., 2015).

\section{Biological Diversity}

The determination of plant diversity was carried out by analyzing exhaustive inventories of species belonging to $W$. frutescens in the four study stations. The study was based on species accounting with the identification of their morphological and biological types (F.Z. El Alalaoui Faris et al., 1999).

\section{Bioclimatic Study}

Bioclimatic analysis of the study area was conducted during two periods (1960-1970) and 2010-2019. Terra Climate database was used as a source of climatic data (Abatzoglou et al., 2018). Bioclimatic parameters (precipitation, minimum, and maximum temperature) were determined using the Ombrothermal diagram (Debrach, 1953; Bagnouls and Gaussen, 1957).

\section{Morphometric Study}

The morphometric study was undertaken to measure the growth of length, stems, and width of the clumps of $W$. frutescens collected from the four study areas. The measurements were conducted using the protocols described by Musundire et al. (2012). 

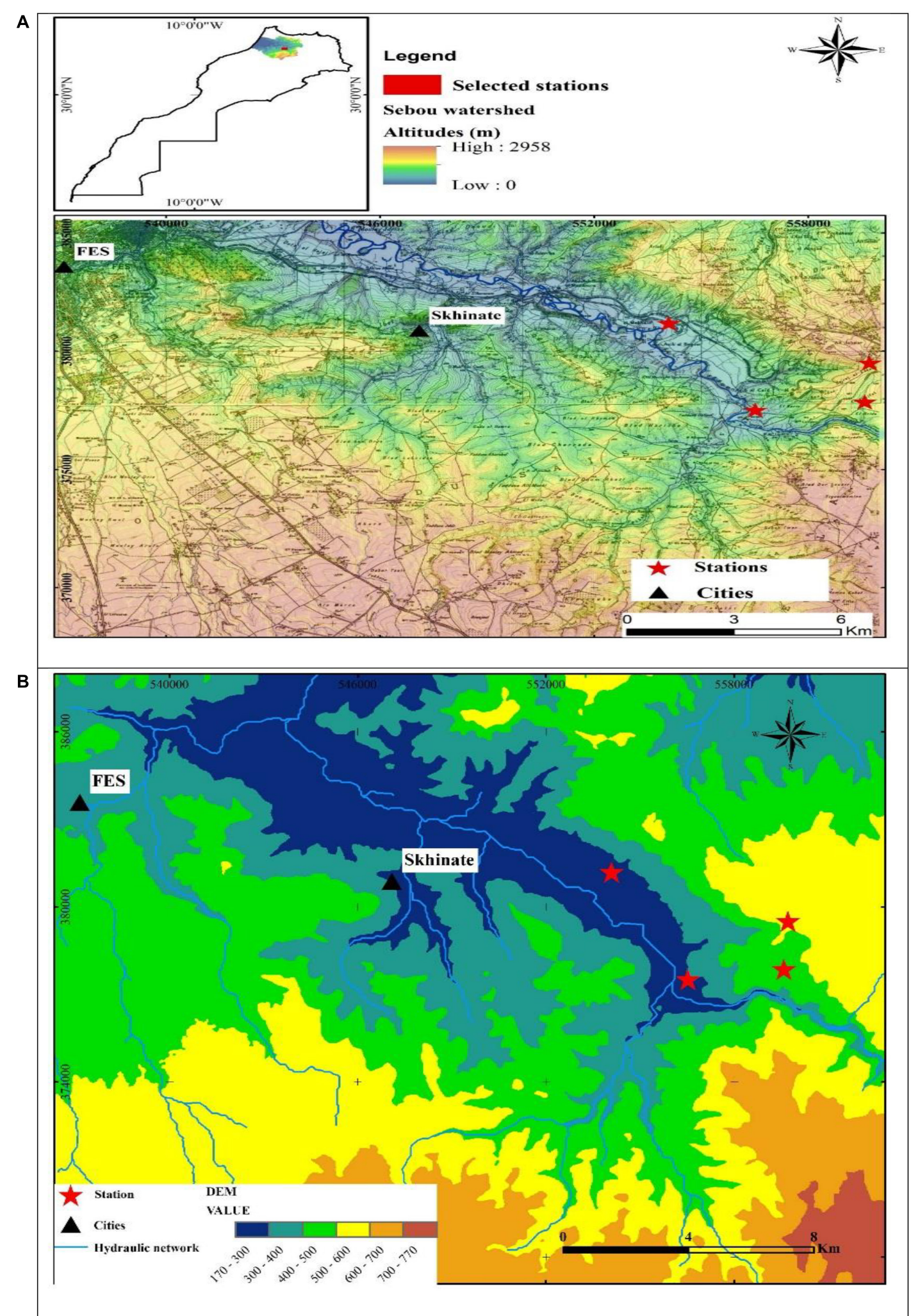

FIGURE 1 | Geological maps of the study stations (A1, A2, A3, and A4). (A) Locations of the study stations; (B) Digital Terrain Model (DTM). 


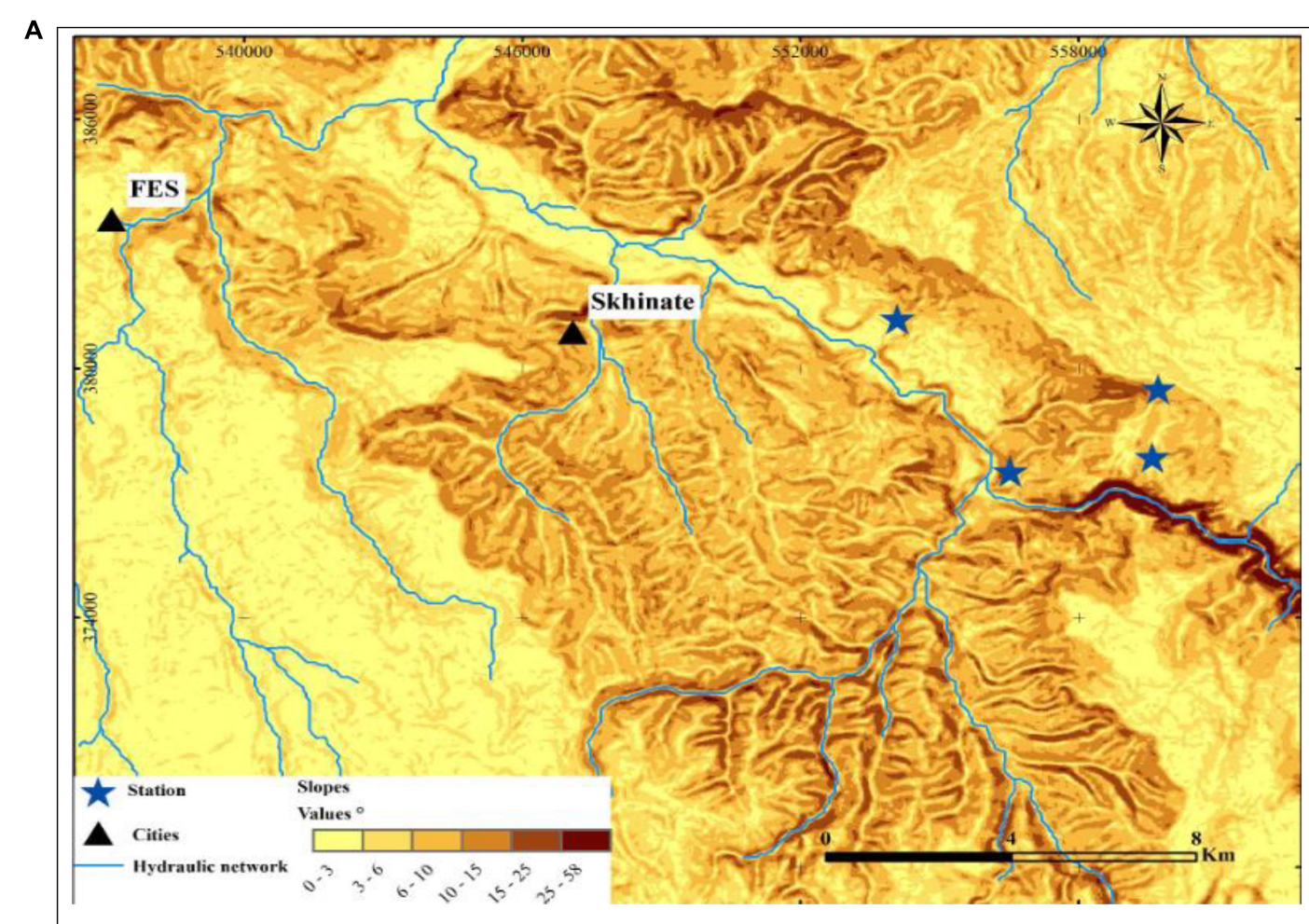

B

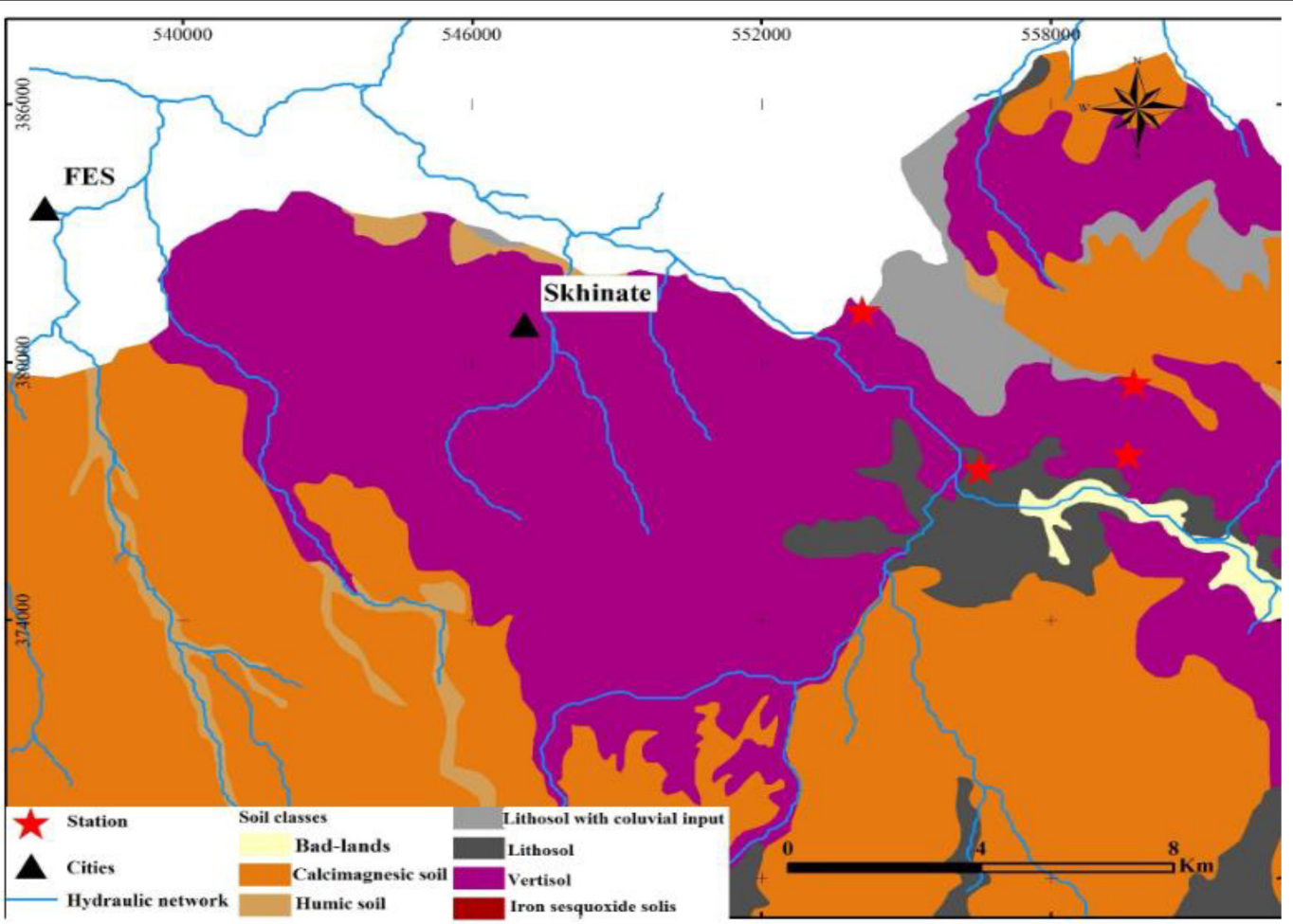

FIGURE 2 | Geological maps of the study stations (A1, A2, A3, and A4). (A) Map of slope classes; (B) soil map. 
TABLE 2 | Physico-chemical characteristics of the soil at the study stations.

\begin{tabular}{|c|c|c|c|c|}
\hline & A1 & A2 & A3 & A4 \\
\hline Soil depth & $0-30 \mathrm{~cm}$ & $0-30 \mathrm{~cm}$ & $0-30 \mathrm{~cm}$ & $0-30 \mathrm{~cm}$ \\
\hline Soil texture & Loamer & Loamer & Loamer & Loamer \\
\hline Color munsell & 7.5 YR (5/2) & 7.5 YR (4/2) & 7.5 YR (4/2) & 7.5 YR (4/2) \\
\hline $\mathrm{pH}$ & $7.035 \pm 0.021$ & $7.095 \pm 0.091$ & $7.225 \pm 0.077$ & $7.175 \pm 0.148$ \\
\hline $\mathrm{CaCO}_{3}(\%)$ & $13.765 \pm 0.473$ & $15.75 \pm 0.77$ & $10.865 \pm 0.586$ & $10.855 \pm 0.60$ \\
\hline Electrical conductivity ( $\mu$ /cm) & $0.425 \pm 0.106$ & $0.625 \pm 0.035$ & $0.675 \pm 0.035$ & $0.75 \pm 0.141$ \\
\hline$\% \operatorname{cox}$ & $2.165 \pm 0.021$ & $2.32 \pm 0.028$ & $2.725 \pm 0.035$ & $2.5 \pm 0.070$ \\
\hline Estimated percentage of organic matter & Medium & Medium & Medium & Medium \\
\hline
\end{tabular}

\section{Histological Analysis of Plant Tissues}

In the current study, the leaves, stems, and roots of $W$. frutescens were histologically investigated to highlight the tissue types existing in their structures (Homès, 1960). To achieve this objective, iodine green and alum carmine were used for staining lignified (xylem) and cellulosic (phloem) tissues, respectively.

\section{The Space-Time Variation of Polyphenol Content}

The variation of phytochemical compounds in $W$. frutescens was investigated at two study stations; each sample was randomly taken each week (month 7-month 10) and 3 weeks after the first rainfall. Chemical compounds were assessed according to the earlier works (El Moussaoui et al., 2019).

\section{Identification of Phytochemical Compounds}

In the present work, the $W$. frutescens that grew in two different stations (A1 and A3) was subjected to a chemical analysis to evaluate the potential effects of climate on this aspect. These stations were reported to have different climates and altitudes to the other stations, so they could influence the chemical composition of the studied plants. The phytochemical identification of $W$. frutescens extracted from stations $\mathrm{A} 1$ and $\mathrm{A} 3$ was done by GC-MS after silylation by N-methyl-Ntrimethylsilyl (MSTFA). Briefly, a total of $3 \mathrm{mg}$ of the studied sample was mixed with $200 \mu \mathrm{L}$ of MSTFA before being heated at $37^{\circ} \mathrm{C}$ for $30 \mathrm{~min}$. Afterward, $0.1 \mu \mathrm{L}$ of the extract was injected into a gas chromatograph coupled to a mass spectrophotometer (Model 5973 from Brand Agilent Technologies) for analysis. Helium was used as carrier gas with a typical pressure (psi) of $0.9 \mathrm{~mL} / \mathrm{s}$. The furnace temperature program was set to $70-270^{\circ} \mathrm{C}$ at $4^{\circ} \mathrm{C} / \mathrm{min}$ and then maintained at $270^{\circ} \mathrm{C}$ for $20 \mathrm{~min}$. The temperature of the injector was set to $280^{\circ} \mathrm{C}$ and that of the detector to $290^{\circ} \mathrm{C}$. The injection was carried out in fractionated mode (El Moussaoui et al., 2020).

\section{Statistical Analysis}

The statistical analysis was conducted using CANOCO version 4.5 and GraphPad prism version 7. Results were expressed as mean \pm SD of triplicate assays.

\section{RESULTS AND DISCUSSION}

\section{Pedological Study}

Soil is the upper layer of earth in which plants grow, but each living species has own individual requirements in terms of minerals and water (Jean-Michel et al., 2010).

In the current study, soil texture was found to be silty at all the studied stations (Table $\mathbf{2}$ and Figure 2B). Further analysis of the soil showed that $W$. frutescens can grow in four soil types: in the first station (A1) with a lithosol input: in a vertisol soil in the second station (A2): with stations A3 and A4 characterized by the presence of calcimagnetic and lithosol soils, respectively. Generally, the soils in the stations were very diversified with a variety of physicochemical characteristics. This diversity is impacted by the lithology of the geological substrate topography and weather events (climate) (Gaouar, 1980). Limestone was present in the soils of the study stations with an average ranging from 10.80 to $15.80 \%$, which can explain the tendency toward both physical and chemical equilibrium. Moreover, calcium plays a predominant role in the physical behavior of soil through the flocculating power. The $\mathrm{pH}$ generally remained neutral (between 7 and 7.2) acrose the sations. Organic matter, electrical conductivity, and salinity were lower in all study stations.

\section{Bioclimatic Study}

The thermal classification of climates proposed by Debrach (1953) was used to perform the current work. In the present study, we noted that stations of both periods, old (19601970) and new (2010-2019), were subjected to half-continental climates. Moreover, all study areas belonge to the wet and dry climatic region with the temporary flow and herbaceous formation. Emberger's chromatograms showed Q2 values with bioclimatic stages from Saharan to wet for the weather stations (Emberger, 1930). All the indications pointed to intense aridity for the studied stations, which can be expressed by a dry season from May to September with high potential for evapotranspiration and almost zero rainfall. Consequently, these harsh climate conditions disturb plant growth in addition to its formations in the study stations. This ultimately leads to the substitution of mesophytic vegetation by xerophytic vegetation in varying degrees (Gaouar, 1980). The bioclimatic study allowed us to highlight a Mediterranean-type climate in the study area. The climate has been characterized by two periods: a cold winter from October to Marchwith irregular rainfall, and a dry summer for 
A1

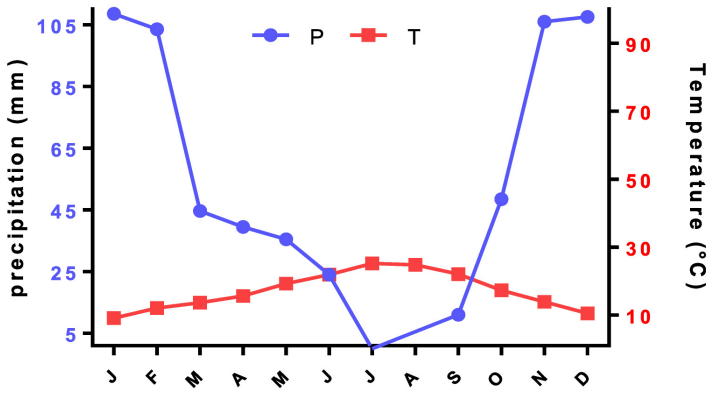

A2

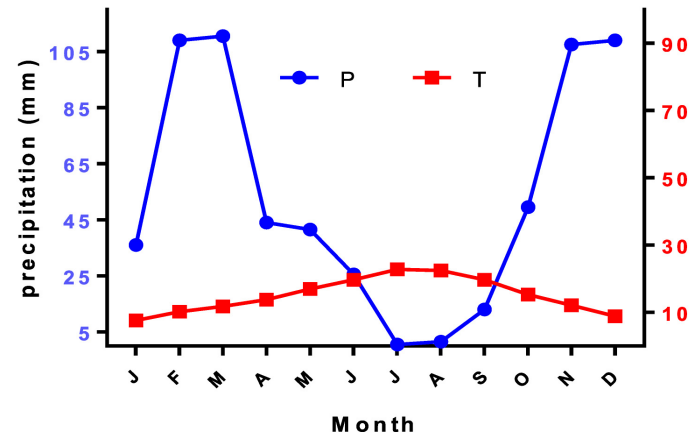

A3

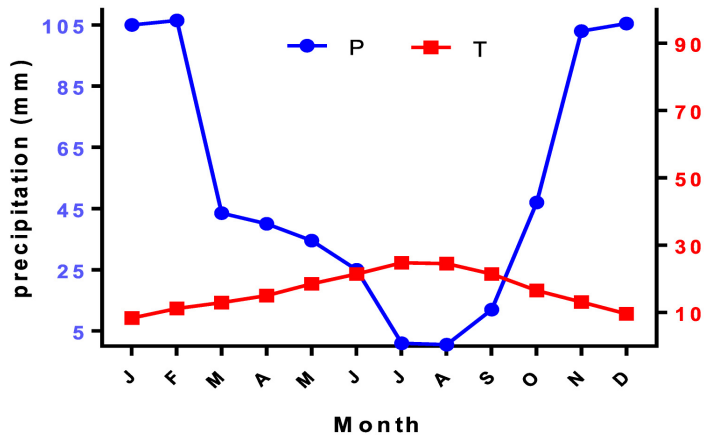

A4

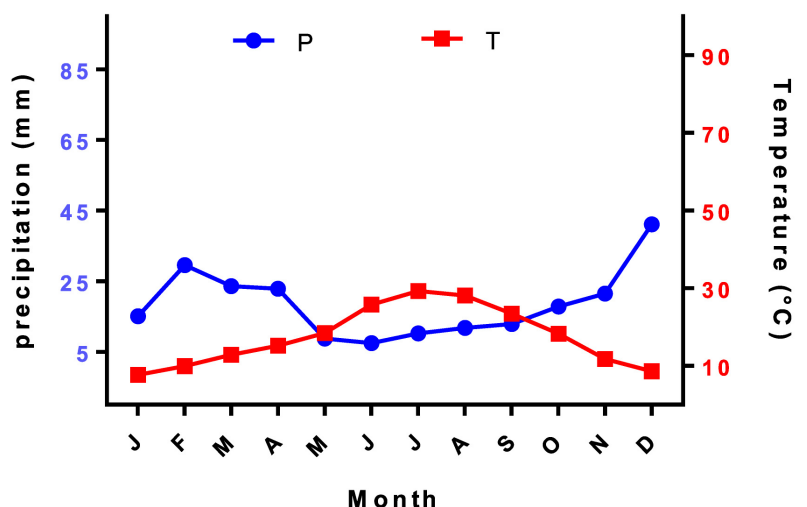

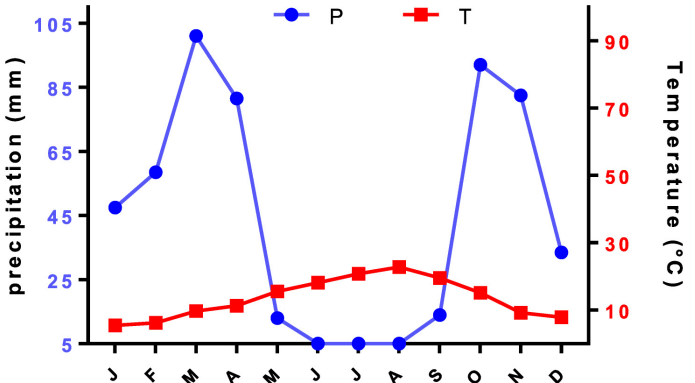

Month

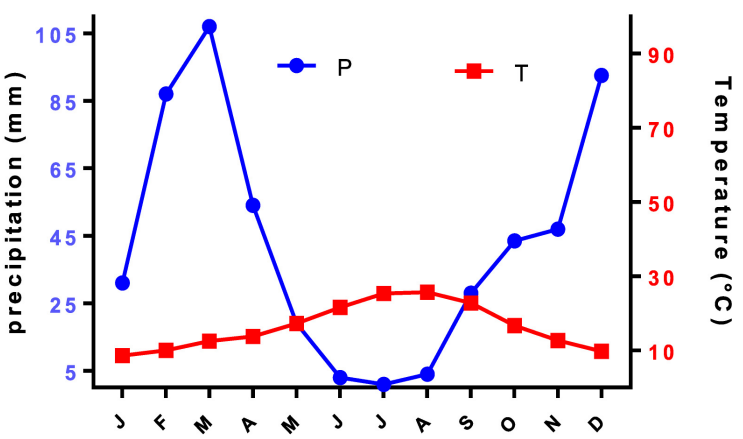

Month

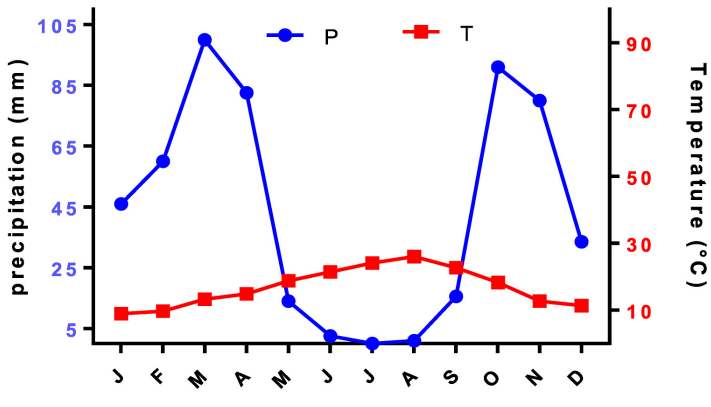

Month

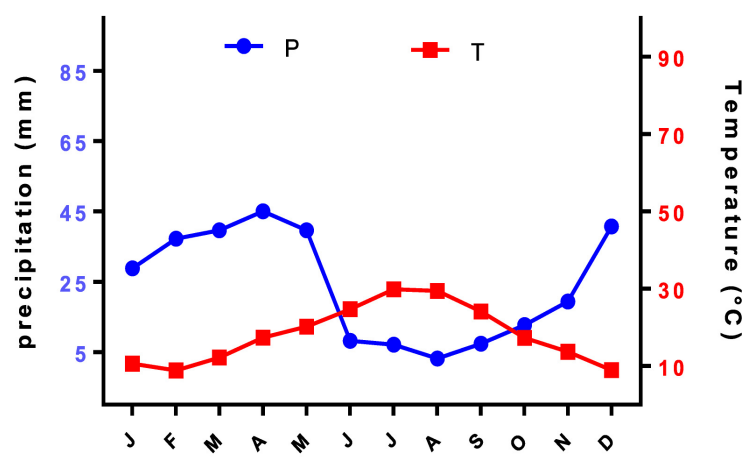

Month

FIGURE 3 | Ombrothermal diagram of studied stations for the new (2010-2019) and old (1960-1970) periods. 
7-8 months marked by a lack of rainfall and high temperatures (Figure 3). Generally, the climate was relatively dry throughout the region with a rainfall of less than $600 \mathrm{~mm}$ Winter and spring were the wettest seasons.

Precipitation plays a major role in defining global climate drought. Rainfall deficit is one of the main components that contributes to the desertification of drylands. The rainfall pattern is influenced by two groups of factors: geographical (altitude, latitude, distance to the sea, orientation of slopes) and meteorological (air masses, the center of the action, the trajectory of low-pressure systems) (Table 3; Halimi, 1980).

\section{Plant Diversity}

The plant species were collected from the study area east south east of Fez City, Morocco. Next, the plant species was identified by botanist Amina Bari and given the voucher specimens BPRN 69 before being deposited at the herbarium of the Department of Biology, Faculty of Sciences, Dhar El Mahraz, Fez, Morocco. The identification was done using guidelines as reported in an earlier work (El Alalaoui Faris et al., 1999). The biological inventory revealed that the study areas' flora consisted of 74 species from different families (Table 4). However, most of the families present in the stations were Poaceae, and Asteraceae, followed by Apiaceae and Lamiaceae in low proportions (Halimi, 1980). The biological form of the plants had been modified due to difficult environmental conditions (Polunin, 1967).

Therophytes represent the highest life form in all studied stations, meanwhile other forms such phanerophytes, chamaephytes, hemicryptophytes, and geophytes equally occupied the area (Figure 4A).

The proportion of morphological type results revealed that each form was consistent with each other across stations. Annual herbaceous plants dominated the study area, followed by perennial herbaceous and perennial woody (Figure 4B). From the morphological point of view, the plant communities in the study stations were marked by heterogeneity between woody and herbaceous, and between perennials and annuals. Variation in ecological factors (biotic and abiotic) could induce changes in the plant distribution, which can be associated with the emergence of herbaceous plants when environmental conditions are unfavorable (Stambouli-Meziane and Bouazza, 2013).

\section{Morphometric Study of $W$. frutescens}

Morphometry represents the relationship between shape and size; morphological changes are strictly induced by growth variations (Musundire et al., 2012). The results of the morphometric study of $W$. frutescens showed that plant sizes differed across study stations (Figure 4C). The morphometric changes observed in $W$. frutescens are probably due to the fact that the species has undergone anthropozoic and grazing actions (Gaouar, 1980). The analysis of plant leaf surfaces allows the understanding of the mechanism of adaptation and acclimatization under drought conditions. The results obtained showed that the largest leaves were recorded for station A3 followed by station A2, whereas the smallest were recorded for stations A1 and A4 (Figure 4D).
The climatological studies (rainfall and precipitation) allowed us to investigate the aridity of the study areas. The physicochemical parameters of the soil determined the form and biological type of the plant species (biological inventory), while the morphometry of $W$. frutescens (length, width, and leaf area) characterized individuals among species in the four studied sites (A1, A2, A3, A4). The results of the statistical analysis (Figure 5) showed that there was a correlation between the vegetation cover (woody perennial and phamerophytes) in stations A1 and A2. Station A3 was characterized by a vegetation cover dominated by perennial herbaceous and therophytes. On the other hand, station A4 was dominated by a vegetation cover of annual herbaceous types, including geophytes, chamerophytes, and hemicryptophytes. Concerning the morphometry of $W$. frutescens, the statistical analysis showed that the high length and the large leaf surface were found in station A3, unlike the small width was found in stations A2 and A1. The climatological studies showed that zone 4 was the aridest with a negative correlation with rainfall and rainfall quotient.

Response mechanisms to the precipitation fluctuations have been well investigated elsewhere (Wright et al., 2004; Sandel and Low, 2019). It was reported that the response mechanisms result in morphology and physiological changes in the plant. In this sense, an increase in precipitation increases plant height, leaf area, and carbon content in leaf alongside leaf nitrogen content, meanwhile decreasing the content of dry matter in leaf and leaf thickness, suggesting that plants may adapt to precipitation changes by modifying the specific traits. It is the fitting that our results are in agreement with this literature (high length and the large leaf surface were found in station A3, small width was found in stations A2 and A1).

Some traits involved in adaptation to water deficit determine the development of the plant or its architecture such as phenology, growth stoppage date, leaf area development, size and depth of the root system, xylem characteristics, and storage. These traits can be constitutive or induced in the long or short term by the application of a water deficit (Passioura, 2006).

Overall, when the limits of tolerance and adaptation to hot climate exemplify in a plant, many modifications can occur at physiological levels, which adversely affect the growth and development and may lead to plant death (Nievola et al., 2017). Temperature changes may result in different structures of plant height and leaf area. Moreover, the physiological responses of plants to heat might be shown in the form structure ( $\mathrm{Li}$ et al., 2018). Therefore, the findings obtained in this work were in accordance those reported in the literature since the $W$. frutescens morphology differed according to temperature fluctuations in study stations (Figures 3, 4).

Many studies have been devoted to the response of biodiversity based on the constraints of climatic variations, however, scientific data on the mechanisms of the adaptation of biodiversity to climatic variations remain scattered, and understanding is still limited (Atkins and Travis, 2010; Taylor and Larson, 2019). The plant species has physiological optimums that conditions their ecological niches. The mechanisms of adaptation can be different according to the species, for example in the case of the adaptation of biodiversity to temperature and rainfall 
TABLE 3 | Determination of bioclimatic syntheses according to continentality, aridity, and pluviothermic ratio climatic indices in the four stations.

\begin{tabular}{|c|c|c|c|c|c|c|c|c|}
\hline \multirow[b]{2}{*}{ Station } & \multirow[b]{2}{*}{ Period } & \multirow[b]{2}{*}{$\mathbf{P}$} & \multicolumn{2}{|c|}{ Continentality index } & \multicolumn{2}{|c|}{ Aridity index } & \multicolumn{2}{|c|}{ Q2 pluviometric } \\
\hline & & & M-m & Climate & Indice & Climate & Q2 & Bioclimate \\
\hline \multirow[t]{2}{*}{ A1 } & $\mathrm{AP}$ & 624.5 & 31.6 & Half-continental & 20.61 & Humid & 67.38 & H, T; Sub, H \\
\hline & NP & 527 & 32.75 & Half-continental & 16.93 & dry & 54.71 & H,T; Semi,A \\
\hline \multirow[t]{2}{*}{$\mathrm{A} 2$} & $\mathrm{AP}$ & 647.5 & 31.6 & Half-continental & 21.98 & humid & 70.06 & H, T; Sub, H \\
\hline & NP & 543.5 & 33.5 & Half-continental & 17.76 & dry & 55.25 & $\mathrm{H}, \mathrm{T} ;$ Semi,A \\
\hline \multirow[t]{2}{*}{ A3 } & $\mathrm{AP}$ & 623.5 & 31.75 & Half-continental & 21.22 & humid & 67.16 & H, T; Sub,H \\
\hline & NP & 526 & 33.55 & Half-continental & 17.17 & dry & 53.39 & H,T; Semi,A \\
\hline \multirow[t]{2}{*}{ A4 } & $\mathrm{AP}$ & 225.91 & 34.55 & Half-continental & 8.68 & dry & 20.41 & $\mathrm{H}, \mathrm{T} ; \mathrm{A}$ \\
\hline & NP & 294.48 & 34.63 & Half-continental & 11.38 & dry & 25.47 & $\mathrm{H}, \mathrm{T} ; \mathrm{A}$ \\
\hline
\end{tabular}

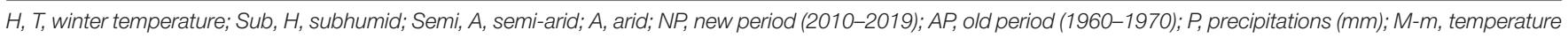
range $\left({ }^{\circ} \mathrm{C}\right) ; \mathrm{Q} 2$, rainfall quotient.

TABLE 4 | Plant species recorded in Withania frutescens (L.) Pauquy formations.

Aegilops ovata L.

Agropyron repens (L.) Gould

Ajuga iva (L.) Schreb

Anagallis arvensis subsp. phoenicea (Gouan)

Anagallis arvensis subsp. latifolia (L.) Arcang

Arenaria emarginata Brot.

Arisarum vulgare O. Targ. Tozz.

Aristolochia longa L.

Asparagus albus L.

Trifolium spumosum $\mathrm{L}$.

Asteriscus maritimus (L.) Greuter

Pallenis maritima (L.) Greuter

Atractylis carduus (Forssk.) Christ

Atractylis concellata $\mathrm{L}$.

Avena sterilis L.

Ballota hirsuta Benth.

Bellis annua L.

Brachypodium distachyon (L.) P.Beauv.

Briza minor L.

Bromus madritensis (L.) Nevski

Anisantha rubens (L.) Nevski

Bryonia dioica Jacq.

Rumex bucephalophorus L.

Calendula arvensis L.

Carduus pycnocephalus L.
Centaurea pubescens Willd.

Centaurea pungens Pomel

Chamaerops humilis L.

Glebionis coronaria (L.) Cass. ex Spach

Convolvulus althaeoides L.

Convolvulus tricolor L.

Cynodon dactylon (L.) Pers.

Cynoglosum cherifolium L.

Dactylis glomerata L.

Daucus carota L.

Erodium moschatum (L.) L'Hér.

Eryngium maritimum L.

Euphorbia peplus L.

Fagonia cretica L.

Fedia cornucopiae (L.) Gaertn.

Fumana thymifolia (L.) Spach ex Webb

Hordeum murinum $L$.

Dittrichia viscosa (L.) Greuter

Lagurus ovatus (L.)

Leucanthemum paludosum (Poir.) Pomel

Malva sylvestris $L$.

Marrubium vulgare $\mathrm{L}$.

Medicago minima L.

Mercurialis annua L.

Nerium oleander L.
Olea europaea L.

Pallenis spinosa (L.) Cass.

Papaver rhoeas L.

Phagnalon saxatile (L.) Cass.

Plantago albicans L.

Plantago coronopus L.

Plantago lagopus L.

Reichardia tingitana (L.) Roth

Reseda alba L.

Rubia peregrine L.

Senecio leucanthemifolius Poir.

Senecio vulgare L.

Sideritis montana L.

Sinapis alba L.

Sinapis arvensis L.

Smilax aspera L.

Smyrnium olusatrum L.

Dioscorea communis (L.) Caddick \& Wilkin

Thapsia garganica $\mathrm{L}$.

Trifolium campestre Schreb.

Ulex parviflorus Pourr.

Urginea maritima (L.) Baker

Withania frutescens (L.) Pauquy

Ziziphus lotus (L.) Lam. variations. The changes in the abundance of species, and cascading mechanisms of reorganization of multispecies and multi-trophic communities occur secondly within ecosystems (Urban et al., 2016).

\section{Histological Study of W. frutescens}

The histological study that was conducted on the leaves, stems, and roots of $W$. frutescens allowed the explanation of certain histological modifications. The results obtained describe the organ tissues, from the outside to the inside, as follows: epidermis, cortical parenchyma, libero-linear bundles (phloem, xylem), and chlorophyllous palisade parenchyma (Figure 6). The histometric results showed that the lacunae and palisade parenchyma were the thickest, whereas the xylem was less thick when compared to the first tissues. Moreover, an alteration between phloem and epidermis was also observed. Tissues were characterized by the absence of collenchyma and the presence of significant correlation at the level of the epidermal cells, which form a compact whole that provides plant organs with effective mechanical protection against evapotranspiration (Figure 6A; Collin, 2001; De Micco and Aronne, 2012).

The observation of the histological sections of stems indicated the following tissue characteristics; from the outside to the inside: epidermis; cortical parenchyma; libero-linear bundles: primary xylem, secondary xylem, and phloem; medullary parenchyma. The histometric study conducted on the stems of $W$. frutescens revealed an important thickness for cortical parenchyma and xylem that ensures the conduction of raw sap (water and mineral salts) from the bottom to the top (Figure 6C; Collin, 2001; De Micco and Aronne, 2012).

Cross-sections of $W$. frutescens roots were found to be axially symmetrical. Two parts could be distinguished: the bark (epidermis and cortical parenchyma) and the central cylinder (Medullary parenchyma and the libero-linear bundles, xylem and phloem). The histometric evaluation revealed that the xylem dominates with a very large thickness, followed by the cortical parenchyma, phloem, medullary parenchyma, and epidermis (Figure 6B). 
A

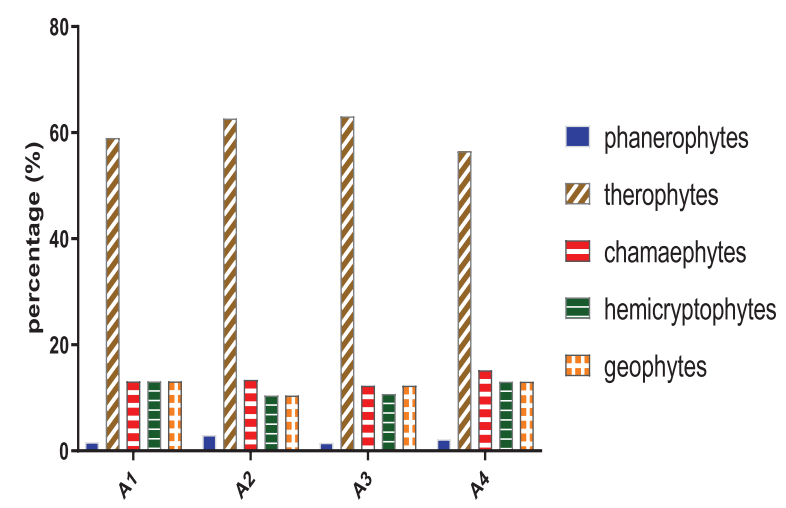

C

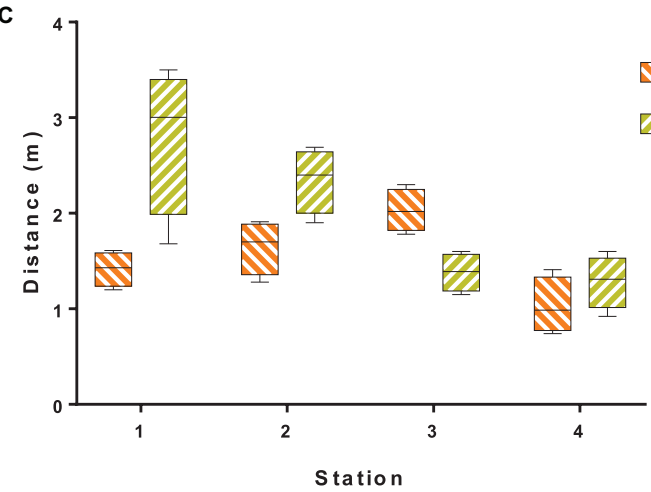

B

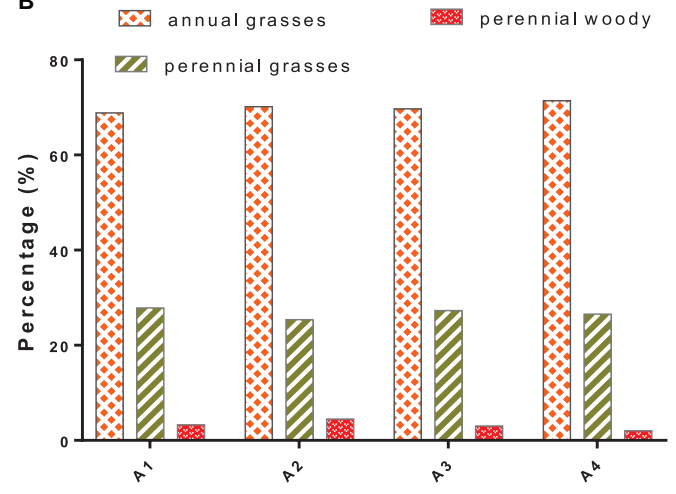

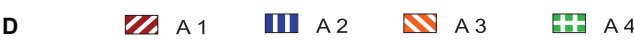

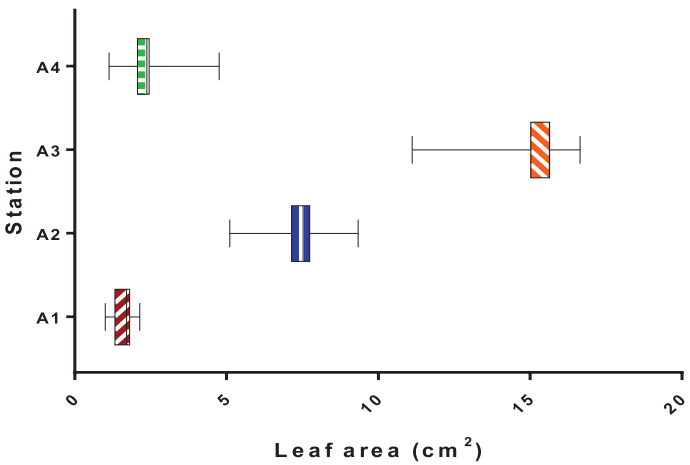

FIGURE 4 | (A) Percentages of plant life forms in the study area. (B) Percentages of morphological types. The length and width (C) and leaf area (D) of Withania frutescens (L.) Pauquy in study stations.

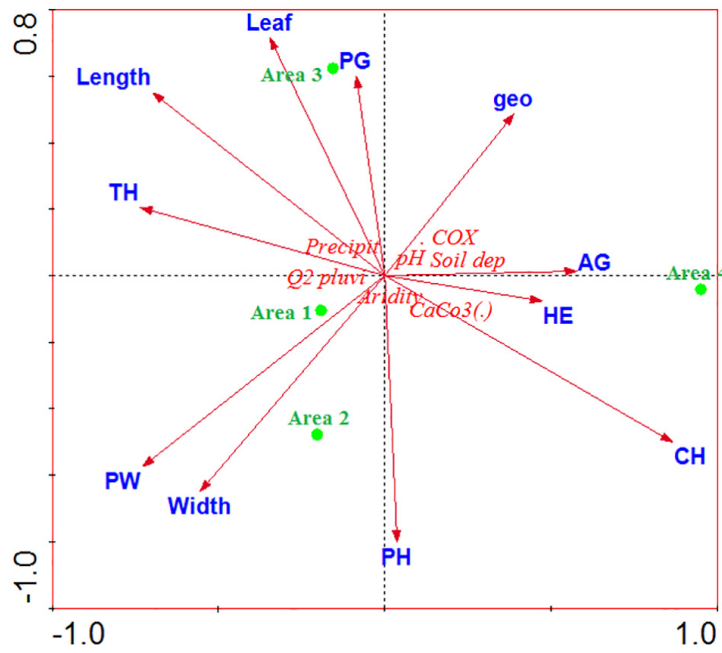

FIGURE 5 | Analysis of the main components of ecological parameters, vegetation and morphometry; AG, annual grasses; PW, perennial woody; PG, perennial grasses; $\mathrm{PH}$, phanerophytes; $\mathrm{TH}$, therophytes; geo, geophytes; HE, hemicryptophytes; $\mathrm{CH}$, chamaephytes.
The histological study of $W$. frutescens revealed that young leaves, stems, and roots were found to be different in terms of the size and shape of their cells as well as their skeletal walls. The results reported in the current study showed that there was a difference in the tissue thickness of plant organs according to the collection site. The tissue dimensions provide information on the physiological state of the plant and its environment (saline and hydric stress, etc.). In the current study, the chlorophyllous palisad parenchyma was found to be more developed in leaves. This result can be explained by the functional role of leaves in assimilation. The presence of the collenchyma type supports tissues in the root and stem, which contribute to the plant's rigidity and solidity. The xylem and phloem occupy an important space in both leaves and roots. These histologic characteristics allow plant species to keep a sufficient hydration rate and also to ensure osmosis phenomena (Collin, 2001; De Micco and Aronne, 2012).

Under harsh environmental conditions, plants can develop new forms as a response to environmental changes. In this sense, morphological and physiological variations occurred in plants along with structural modification at the level of the tissues to continue to survive. For performing a comparison of selected 

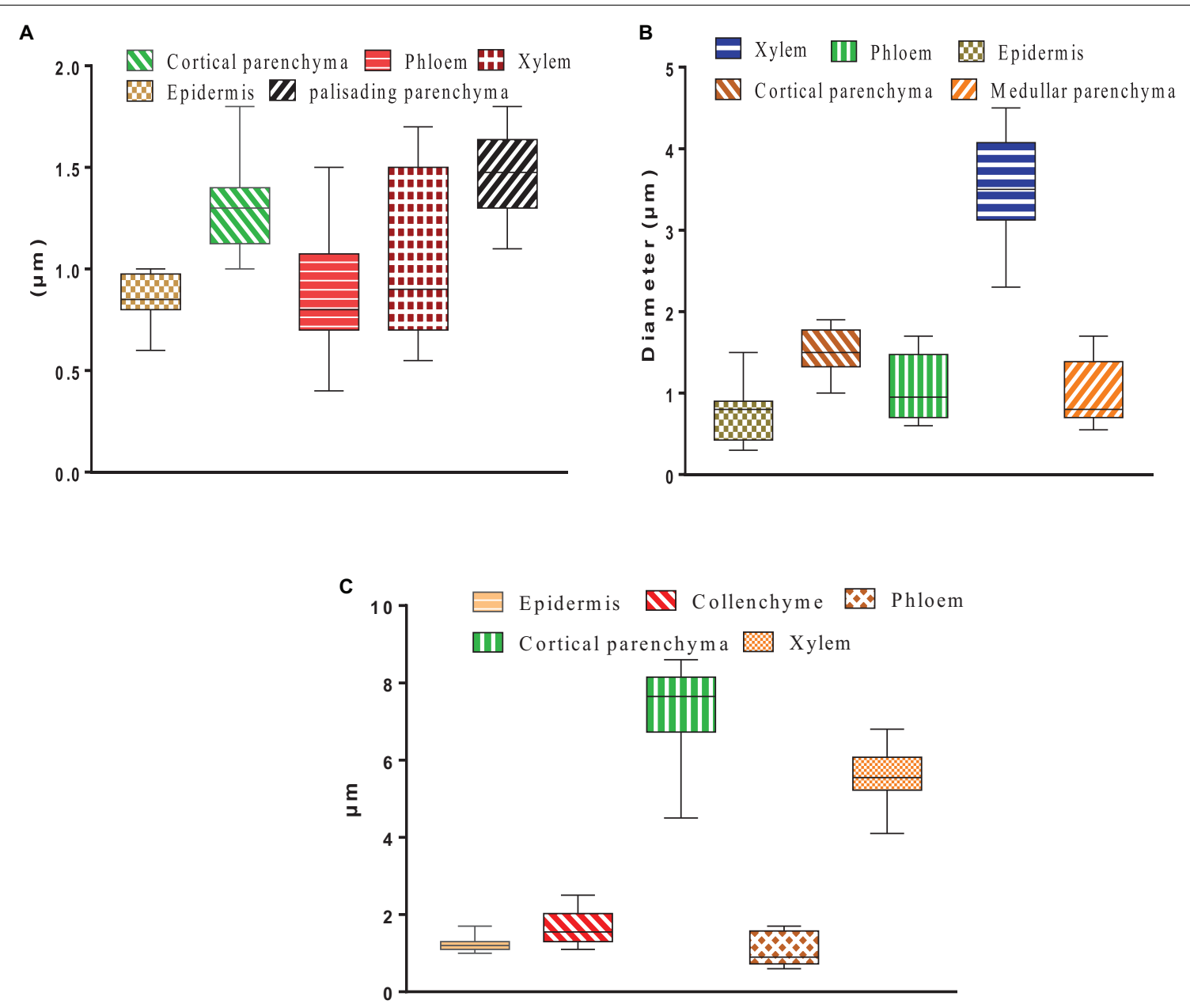

FIGURE 6 | (A) Leaf tissue thickness. (B) Histometry of root cross sections. (C) Histometry of stem cross sections of Withania frutescens (L.) Pauquy.

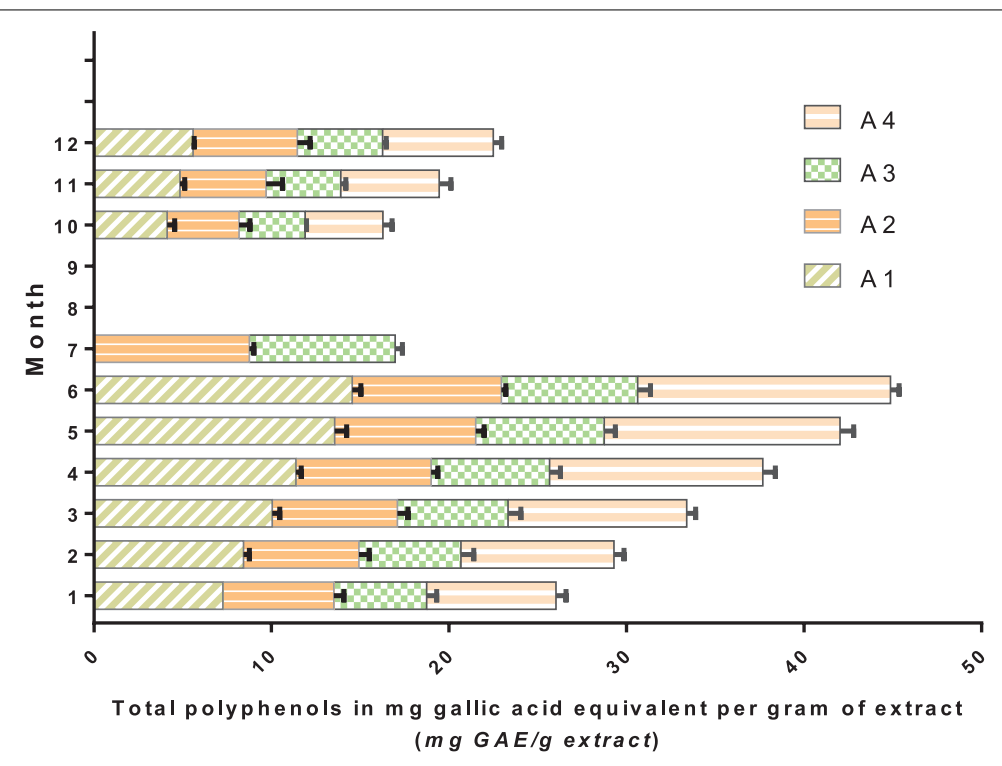

FIGURE 7 | Variability of total polyphenols in Withania frutescens (L.) Pauquy shown by month. 
climatic periods, it was found that there was an increase in the duration of the dry period and a decrease in the wet period (Figure 3). Thus the tissue modification can be a means of adaptation of the plants to drought (Calatayud et al., 2013).

\section{The Space-Time Variation of Polyphenol Content}

Determination of total polyphenols during the first week of leaf partitioning and a few weeks after the first rainfall allowed us to observe the plant variation in polyphenol concentrations at the study stations. High levels of polyphenol content were recorded during the dry period (month 6) at all stations (a period of water stress, i.e., lack of rain, and increasing temperatures) (Figure 7). Stations A1 and A4 had elevated concentrations of polyphenol content, 14.55 and $14.25 \mathrm{mg}$ GAE/g, respectively. These stations had been exposed to a high altitude facing south with high atmospheric heat, which can explain this variation (Achakzai et al., 2009). In July, it was found that the majority of leaves fell at both stations (A1 and A4), unlike the stations. This effect can be due to the stations' microclimate since stations A1 and A4 were exposed to the south with high altitude, unlike stations A2 and A3 which are located in a valley with a low altitude (Gaouar, 1980).

It was observed that in response to the concomitant action of multiple abiotic stressors and harsh conditions, plants activate the biosynthesis of multifunctional polyphenols as an adaptation response to drought (Tattini et al., 2000). This metabolic pathway can profoundly affect the plant architecture, although it provides additional protection against stress events which is very beneficial. Moreover, polyphenols have the greatest potential to perform multiple functions in plants exposed to abiotic stresses (Agati et al., 2012, 2013). Polyphenol content increases in plants exposed to various abiotic stressors, especially in the cell wall (Bussotti et al., 1998; Reig-Armiñana et al., 2004; De Micco and Aronne, 2012). These secondary metabolites are involved in plant cell wall thickening leading to changes in the functions of plant organs, and increasing tissue strength, thereby providing better drought tolerance. In addition, polyphenol-induced mechanical strengthening of cell walls coupled with chemical-related effects may also improve resistance and adaptation to abiotic and biotic stress (Bennett et al., 1996; McLusky et al., 1999; Agati et al., 2012; Gunnaiah et al., 2012).

\section{Identification of Phytochemical Compounds}

In the current research, we studied the effect of climate on the chemical content in $W$. frutescens growing in two stations (A1 and A3) with different climates and altitudes. The comparative study was conducted to screen whether there were variations in chemical content in samples collected simultaneously from a plant grown under different environmental conditions. It was found that the chemical composition of the plants collected from station A1 was identified with eight compounds (Supplementary Figure 1 and Supplementary Table 1), among them 1,1'-Biphenyl, 3'-(1,1-dimethylethyl)-5'-methyl-2,6-dinitro was the major component with an area percentage of 29.16. In station A3, the chemical composition of the plants was identified with six compounds (Supplementary Figure 2 and Supplementary Table 2), among them 1-methyl-2-(pnitrophenyl)-benzimidazole was the most dominant with an area percentage of 40.73. The findings obtained showed that the identified compounds differ in station A1 when compared to A3 except for the morphine, which was found in both stations but with different area percentage: A1 with $12.43 \%$ vs. A3 with $3.44 \%$. These findings were in agreement with those reported in earlier works, which showed that changes that occurred in the climate and physicochemical parameters of the soil affect the chemical composition in plants. Moreover, plants grown under stresses mobilize the entire metabolic pathways for acclimatization and survival in their natural environment (Chaves et al., 2010).

\section{CONCLUSION}

In the current study, we presented an overview of responses of $W$. frutescens to various abiotic and abiotic stresses. The responses of $W$. frutescens to environmental stress were discussed in the light of topographical, climatological, morphological, histological, and phytochemical aspects. It was found that adaptation to stress may differ according to the plant's interactions with the microenvironment. The impact of climatic changes on $W$. frutescens and its susceptibility to stress should be considered to prevent wide damages that may occur to this species. It is well understood that the possible mechanisms involved in stressful conditions can be a key issue for the appropriate management of natural resources. In summary, we can confirm that $W$. frutescens has developed various adaptation strategies to persist under harsh ecological conditions.

\section{DATA AVAILABILITY STATEMENT}

The raw data supporting the conclusions of this article will be made available by the authors, without undue reservation.

\section{AUTHOR CONTRIBUTIONS}

$\mathrm{AM}$ and MB: writing the original draft. FJ, HK, and MC: formal analysis. AKA: revision and editing. AS, AHA, ADA, and HA: revision editing and data curation. $\mathrm{DB}$ and $\mathrm{AB}$ : methodology and supervision. All authors contributed to the article and approved the submitted version.

\section{ACKNOWLEDGMENTS}

The authors extend their appreciation to the Deanship of Scientific Research at King Saud University for funding this work through research group no. RG-1441-360.

\section{SUPPLEMENTARY MATERIAL}

The Supplementary Material for this article can be found online at: https://www.frontiersin.org/articles/10.3389/fevo.2021. 666005/full\#supplementary-material 


\section{REFERENCES}

Abatzoglou, J. T., Dobrowski, S. Z., Parks, S. A., and Hegewisch, K. C. (2018). TerraClimate, a high-resolution global dataset of monthly climate and climatic water balance from 1958-2015. Sci. Data 5, 1-12. doi: 10.1038/sdata.2017.191

Achakzai, A. K. K., Achakzai, P., Masood, A., Kayani, S. A., and Tareen, R. B. (2009). Response of plant parts and age on the distribution of secondary metabolites on plants found in Quetta. Pak. J. Bot. 41, 2129-2135.

Agati, G., Azzarello, E., Pollastri, S., and Tattini, M. (2012). Flavonoids as antioxidants in plants: location and functional significance. Plant Sci. 196, 67-76. doi: 10.1016/j.plantsci.2012.07.014

Agati, G., Brunetti, C., Di Ferdinando, M., Ferrini, F., Pollastri, S., and Tattini, M. (2013). Functional roles of flavonoids in photoprotection: new evidence, lessons from the past. Plant Physiol. Biochem. 72, 35-45. doi: 10.1016/j.plaphy.2013.03. 014

Atkins, K. E., and Travis, J. M. J. (2010). Local adaptation and the evolution of species' ranges under climate change. J. Theor. Biol. 266, 449-457. doi: 10.1016/ j.jtbi.2010.07.014

Bagnouls, F., and Gaussen, H. (1957). Les Climats Biologiques et Leur Classification. Ann. Géogr. 66, 193-220. doi: 10.3406/geo.1957.18273

Benabadji, N., and Bouazza, M. (2000). Contribution à une étude bioclimatique de la steppe à Artemisia herba-alba Asso. dans l'Oranie (Algérie occidentale). Sci. Change. Planét. Sécheresse 11, 117-123.

Bennett, M., Gallagher, M., Fagg, J., Bestwick, C., Paul, T., Beale, M., et al. (1996). The hypersensitive reaction, membrane damage and accumulation of autofluorescent phenolics in lettuce cells challenged by Bremia lactucae. Plant J. 9, 851-865. doi: 10.1046/j.1365-313X.1996.9060851.x

Bourhia, M., Elmahdaoui, H., Moussa, S. I., Ullah, R., and Bari, A. (2020). Potential Natural Dyes Food from the Powder of Prickly Pear Fruit Peels (Opuntia spp.) Growing in the Mediterranean Basin under Climate Stress. Biomed Res. Int. 2020:7579430. doi: 10.1155/2020/7579430

Bussotti, F., Gravano, E., Grossoni, P., and Tani, C. (1998). Occurrence of tannins in leaves of beech trees (Fagus sylvatica) along an ecological gradient, detected by histochemical and ultrastructural analyses. New Phytol. 138, 469-479. doi: 10.1046/j.1469-8137.1998.00121.x

Calatayud, P.-A., Garrec, J.-P., and Nicole, M. (2013). “Adaptation des plantes aux stress environnementaux," in Interactions Insectes-Plantes, eds P. A. Calatayud, F. Marion-Poll, N. Sauvion, P. A. Calatayud, and D. Thiéry (Marseille: Institut de recherche pour le développement), 229-245. doi: 10.4000/books.irdeditions. 22422

Chaves, M. M., Zarrouk, O., Francisco, R., Costa, J. M., Santos, T., Regalado, A. P., et al. (2010). Grapevine under deficit irrigation: hints from physiological and molecular data. Ann. Bot. 105, 661-676. doi: 10.1093/aob/mcq030

Chelli-Chaabouni, A. (2014). "Mechanisms and adaptation of plants to environmental stress: a case of woody species," in Physiological Mechanisms And Adaptation Strategies In Plants Under Changing Environment, eds P. Ahmad, M. Wani (New York, NY: Springer), 1-24. doi: 10.1007/978-1-4614-8591-9_1

Christensen, T. R., Johansson, T., Olsrud, M., Ström, L., Lindroth, A., Mastepanov, M., et al. (2007). A catchment-scale carbon and greenhouse gas budget of a subarctic landscape. Philos. Trans. R. Soc. A Math. Phys. Eng. Sci. 365, 1643-1656. doi: 10.1098/rsta.2007.2035

Collin, P. (2001). L'adaptation au milieu chez les plantes vasculaires Plant adaptations to environmental conditions. Ann. Biol. 40, 21-42. doi: 10.1016/ S0003-5017(01)72083-1

De Micco, V., and Aronne, G. (2012). "Morpho-anatomical traits for plant adaptation to drought," in Plant Responses to Drought Stress: From Morphological to Molecular Features, eds R. Aroca (Berlin Heidelberg: SpringerVerlag), 37-61. doi: 10.1007/978-3-642-32653-0_2

Debrach, J. (1953). notes sur les climats du maroc occidental. Maroc Med. 32, $1122-1134$.

Di Ferdinando, M., Brunetti, C., Agati, G., and Tattini, M. (2014). Multiple functions of polyphenols in plants inhabiting unfavorable Mediterranean areas. Environ. Exp. Bot. 103, 107-116. doi: 10.1016/j.envexpbot.2013.09.012

Diallo, M. D., Ngamb, T., Tine, A. K., Guisse, M., Ndiaye, O., Saleh, M. M., et al. (2015). Caractérisation agropédologique des sols de mboltime dans la zone des niayes (Sénégal). Agronomie Africaine 27, 57-67.
Diffenbaugh, N. S., Pal, J. S., Trapp, R. J., and Giorgi, F. (2005). Fine-scale processes regulate the response of extreme events to global climate change. Proc. Natl. Acad. Sci. U. S. A. 102, 15774-15778. doi: 10.1073/pnas.0506042102

El Alalaoui Faris, F. Z., El Oualidi, J., Fennane, M., Tattou, M. I., Mathez, J., Ouchbani, S., et al. (1999). "Flore Pratique Du Maroc," In Biogeografía de los pteridófitos del Mediterráneo Occidental, eds M. Fennane, M. Tattou, J. Mathez, A. Ouyahya, and J. Oualidi (Rabat: Institut Scientifique, Université Mohammed V - Agdal), 1.

El Moussaoui, A., Bourhia, M., Jawhari, F. Z., Es-safi, I., Ali, S. S., Bari, A., et al. (2020). Withania frutescens. L Extract: phytochemical Characterization and Acute and Repeated Dose 28-Day Oral Toxicity Studies in Mice. Biomed Res. Int. 2020, 1-7. doi: 10.1155/2020/1976298

El Moussaoui, A., Jawhari, F. Z., Almehdi, A. M., Elmsellem, H., Fikri Benbrahim, K., Bousta, D., et al. (2019). Antibacterial, antifungal and antioxidant activity of total polyphenols of Withania frutescens.L. Bio. Chem. 93:103337. doi: 10.1016/ j.bioorg.2019.103337

Emberger, L. (1930). sur une formule climatique applicable en géographie botanique. C. R. Acad. Sci. 191, 389-390.

Gaouar, A. (1980). Hypothèses et réflexions sur la dégradation des écosystèmes forestiers dans la région de Tlemcen (Algérie). Rev. Forêt Méd. 2, 131-146.

Gunnaiah, R., Kushalappa, A. C., Duggavathi, R., Fox, S., and Somers, D. J. (2012). Integrated Metabolo-Proteomic Approach to Decipher the Mechanisms by Which Wheat QTL (Fhb1) Contributes to Resistance against Fusarium graminearum. PLoS One 7:e40695. doi: 10.1371/journal.pone.0040695

Halimi, A. (1980). L’Atlas Blideİen: climats \& è̃tages veİgeİtaux. Alger: Office des publications universitaires.

Homès, J. L. A. (1960). ÉTUdE HISTOLOGIQUE DE LA GREFFE DE GOSSYPIUM HIRSUTUM L. R. Bot. Soc. Begium 92, 11-32.

Jean-Michel, G., Michel, A., and Willy, M. (2010). Le sol vivant. Bases de pédologie. Biologie des sols. Troisième édition. Lausanne: Presses Polytechniques et Universitaires Romandes.

Li, B., Gao, K., Ren, H., and Tang, W. (2018). Molecular mechanisms governing plant responses to high temperatures. J. Integr. Plant Biol. 60, 757-779. doi: 10.1111/jipb.12701

Malhi, Y., Gardner, T. A., Goldsmith, G. R., Silman, M. R., and Zelazowski, P. (2014). Tropical forests in the Anthropocene. Annu. Rev. Environ. Resour. 39, 125-159, doi: 10.1146/annurev-environ-030713-155141

McLusky, S. R., Bennett, M. H., Beale, M. H., Lewis, M. J., Gaskin, P., and Mansfield, J. W. (1999). Cell wall alterations and localized accumulation of feruloyl-3'methoxytyramine in onion epidermis at sites of attempted penetration by Botrytis allii are associated with actin polarisation, peroxidase activity and suppression of flavonoid biosynthesis. Plant J. 17, 523-534. doi: 10.1046/j.1365313X.1999.00403.x

Musundire, R., Chabi-Olaye, A., and Krüger, K. (2012). Host plant effects on morphometric characteristics of Liriomyza huidobrensis, L. sativae and L. trifolii (Diptera: Agromyzidae). J. Appl. Entomol. 136, 97-108. doi: 10.1111/j.14390418.2010.01597.x

Ndiaye, O., Diallo, A., Matty, F., Thiaw, A., Fall, R., and Guisse, A. (2012). Caractérisation des sols de la zone des Niayes de Pikine et de Saint Louis (Sénégal). Int. J. Biol. Chem. Sci. 6, 519-528. doi: 10.4314/ijbcs. v6il.46

Nievola, C. C., Carvalho, C. P., Carvalho, V., and Rodrigues, E. (2017). Rapid responses of plants to temperature changes. Temp. 4, 371-405. doi: 10.1080/ 23328940.2017.1377812

Passioura, J. B. (2006). The perils of pot experiments. Funct. Plant Biol. 33, 1075-1079. doi: 10.1071/FP06223 Available online at: https: //scholar.google.com.au/citationsview_op=view_citation\&hl=en\&user= AK65OVoAAAAJ\&citation_for_view=AK65OVoAAAAJ:37UQlXuwjP4C (Accessed July 9, 2021).

Polunin, N. (1967). Éléments de géographie botanique. Paris: Gauthier-V.

Quezel, P. (1999). Biodiversité végétale des forêts méditerranéennes: son évolution éventuelle d'ici trente ans. Forets Med. 1, 3-8.

Reig-Armiñana, J., Calatayud, V., Cerveró, J., García-Breijo, F. J., Ibars, A., and Sanz, M. J. (2004). Effects of ozone on the foliar histology of the mastic plant (Pistacia lentiscus L.). Environ. Pollut. 132, 321-331. doi: 10.1016/j.envpol.2004. 04.006 
Sandel, B., and Low, R. (2019). Intraspecific trait variation, functional turnover and trait differences among native and exotic grasses along a precipitation gradient. J. Veg. Sci. 30, 633-643. doi: 10.1111/jvs.12756

Stambouli-Meziane H., and Bouazza, M. (2013). FLORISTIC CHARACTERIZATION OF THE STEPPE OF THE AREA OF TLEMCEN $\backslash \mathrm{n}(\mathrm{WESTERN}$ ALGERIA). Int. J. Environ. Ecol. Fam. Urban Stud. 3, 7-20.

Tattini, M., Gravano, E., Pinelli, P., Mulinacci, N., and Romani, A. (2000). Flavonoids accumulate in leaves and glandular trichomes of Phillyrea latifolia exposed to excess solar radiation. New Phytol. 148, 69-77. doi: 10.1046/j.14698137.2000.00743.x

Taylor, S. A., and Larson, E. L. (2019). Insights from genomes into the evolutionary importance and prevalence of hybridization in nature. Nat. Ecol. Evol. 3, 170-177. doi: 10.1038/s41559-0180777-y

Urban, M. C., Bocedi, G., Hendry, A. P., Mihoub, J. B., Pe'er, G., and Singer, A. (2016). Improving the forecast for biodiversity under climate change. Science 353, 1113-1122. doi: 10.1126/science.aad 8466

Valladares, F., Zaragoza-Castells, J., Sánchez-Gómez, D., Matesanz, S., Alonso, B., Portsmuth, A., et al. (2008). Is Shade Beneficial for Mediterranean Shrubs Experiencing Periods of Extreme Drought and Late-winter Frosts? Ann. Bot. 102, 923-933. doi: 10.1093/aob/ $\operatorname{mcn} 182$
Wollenweber, B., Porter, J. R., and Lübberstedt, T. (2005). Need for multidisciplinary research towards a second green revolution. Curr. Opin. Plant Biol. 8, 337-341. doi: 10.1016/j.pbi.2005.03.001

Wright, I. J., Reich, P. B., Westoby, M., Ackerly, D. D., Baruch, Z., Bongers, F., et al. (2004). The worldwide leaf economics spectrum. Nature 428, 821-827. doi: $10.1038 /$ nature 02403

Conflict of Interest: The authors declare that the research was conducted in the absence of any commercial or financial relationships that could be construed as a potential conflict of interest.

Publisher's Note: All claims expressed in this article are solely those of the authors and do not necessarily represent those of their affiliated organizations, or those of the publisher, the editors and the reviewers. Any product that may be evaluated in this article, or claim that may be made by its manufacturer, is not guaranteed or endorsed by the publisher.

Copyright (c) 2021 Moussaoui, Bourhia, Jawhari, Khalis, Chedadi, Agour, Salamatullah, Alzahrani, Alyahya, Alotaibi, Bousta and Bari. This is an open-access article distributed under the terms of the Creative Commons Attribution License (CC BY). The use, distribution or reproduction in other forums is permitted, provided the original author(s) and the copyright owner(s) are credited and that the original publication in this journal is cited, in accordance with accepted academic practice. No use, distribution or reproduction is permitted which does not comply with these terms. 